\author{
Shahin Samadpour Shahrak, \\ M. A. Shabestar Branch, \\ Parviz Karimi Sani, \\ PhD, Department of Psychology, Shabestar Branch, \\ Roghayeh Khamizadeh, \\ PhD, Department of Psychology, Shabestar Branch, \\ Islamic Azad University, Shabestar, Iran
}

\title{
INVESTIGATING THE IMPACT OF PAINTING ON THE LEVEL OF PRE-SCHOOL CHILDREN'S CREATIVITY
}

This study aimed to explore the impact of painting on the creativity level of pre-school children of Shabestar kindergartens in 2014-2015 school year. The present study is quasi-experimental. The study involved 30 kindergarten and pre-school children. Data collection instrument was a standard questionnaire. The data were analyzed in two parts: Descriptive statistics (including demographic data, tables and charts) and inferential statistics (Manoa test and analysis of covariance). The results show that painting has a positive impact on the development of pre-school children's creativity. Moreover, the findings have indicated that painting is an effective tool for the development of initiative and flexibility of children in the Shabestar kindergartens.

Keywords: painting, creativity, fluency, development, initiative, flexibility, preschool children.

\section{Introduction}

In order to pass from the information era to the future world, children must be capable, creative, sociable and be trained on new technologies so that they have high motivation and have the joy of life to be able to endure the competitive and complex future world (Jorjani, 2011). If children are not educated for the future, they will fail in a tough competition and will suffer from mental problems by losing their self-esteem.

Art can provide conditions that enable people to get rid of commotions and enjoy beauty, and thereby become calm and contemplate deeper (Elhami, 2013). Creativity means someone offers new and different thought (Amir Jahani, 2011). According to Astifan Rabins, creativity means the ability to combine ideas and opinions in a unique way by creating coherence between them (Gharika, 2005). Perkins (2012) has referred to six special features in highly creative individuals. According to his theory, creative children can create beauty. They can easily identify issues and go through them with flexibility.

After the age of five, a child enters a kindergarten and is trained with other children. The period from five to six years is considered as the golden age of children's personality formation and has particular sensitivities (Asadi, 2011). Painting and art follow the principles of divergent thinking. Painting makes a child gain new experiences and transfer it to other people and this is the beginning of the exchange of ideas and the emergence of new thoughts.

According to Arnest Dinmeh, one of the founders of French education, when a person conveys his/her new thoughts and experiences to others and brings them out of his/her mind, more new ideas come out of his/her mind and this action causes the activation of the brain to think more (Kazemi, 2012). Painting helps human mind travel in a relaxing environment with freedom, explore and discover new things, and demonstrate ideas that have not yet been experienced (Elhami, 2013). Basically, when the mind becomes restless and abounds with conflict, concerns and troubles, a lot of brain energy is wasted to cope with such chaos and finally becomes exhausted. When the mind is tired, a human is not able to think deeply and tends to carry out repetitive tasks that do not require thinking during the work. If this condition develops in the community, we can speculate to what extent people will tend to think about their works and to follow their activities with reason and thought (Amir Jahani, 2011).

Painting strengthens active imagination which, in turn, can provide a ground for new ideas. Many great inventions derived from the imagination of great people who imagined these inventions in their minds in the past which were then turned into action by others (Mirza Aqaei, 2002).

At pre-school age, children experience art mostly with painting. This period is an important stage of their lives. If they are under the supervision of an experienced mentor who helps them use their imagination freely, they can create artwork that will facilitate their intellectual development and, on the other hand, it will help adults understand the inner nature of child. These characteristics have influenced a lot of world's great artists such as Picasso, Kelehand Matisse whose works were affected by childish expressions (Hosseinzadeh, 2010).

Enjoying such arts as painting helps children understand issues from experience. Painting results in the personality development and self-esteem fostering. It helps children learn how to do creative work and apply their imagination (Taleei, 2013).

Now, it is essential for the responsible authorities to conduct research in order to identify the status of art education in pre-school institutions so that educational activities can be organized properly. If we cannot manage this 
important phase of training, we will loss the golden opportunity to teach creativity to children (Faraji, 2012).

Lots of questions about education and learning during pre-school programs have been raised, for example: What do children learn as preschoolers? How should one communicate with pre-school children? What are the methods of working with children in this period? In addition to playing, what are the needs of pre-school children that should be considered? Accordingly, considering the aforementioned issues, the research question is raised: Has painting a positive effect on the development of preschool children's creativity?

\section{Research methodology}

The method used in this study is quasi-experimental. The study consisted of pre-test and post-test with control and experimental groups. The population size consisted of all pre-school children in Shabestar kindergartens studying in 2014-2015 school year (620 individuals). The survey involved 30 preschoolers who were divided randomly into two groups of 15 individuals. The experimental group participated in the painting training sessions. After finishing these sessions, this group of 15 individuals was compared with the control group which similarly included 15 individuals. The control group had no intervention.

\section{The structure of sessions}

This approach has been developed and produced by William Gordon and his colleagues. Gordon began training creativity groups in the industry and designed it in a way that can be applied for training students. The structure of the methodology included 9 sessions: first session: free theme painting; second session: random drawing (stripe); third session: painting with a certain theme including a) humans b) animals c) fruits d) flowers; fourth session: painting for stories; fifth session: completing the unfinished paintings; sixth session: printing a) printing with natural materials b) printing with synthetic materials; seventh session: integrating painting and crafts; eighth session: combining painting with auditory training; ninth session: combining painting with story and presentation. Before each session, homework of the previous session was reviewed and for each session, appropriate homework was given in accordance with the given topic. Each session takes 30 to 60 minutes.

The tool used in this study to collect data was a standardized creativity questionnaire. The questionnaire has 30 questions and can be used for different ages. The questionnaire for measuring creativity, which is famous as the Abedi Creativity Test (CT), was constructed based on Torrance theory on creativity and was made by Abedi in Tehran in 1984.The reliability of the questionnaire is 0.090. The data were analyzed at two levels. Descriptive statistics including frequency and percentage, sex and the mean and standard deviation of the variables were used in the two groups. In inferential statistic, analysis of covariance was used.

\section{Results}

The distribution of variable scores in the society should be normal. To examine this assumption, the Kolmogorov-Smirnov test was used to assess the normal distribution of data which is presented in Table 1.

Table 1.

Kolmogorov-Smirnov test for examining normality of variables

\begin{tabular}{|c|c|c|c|}
\hline Rank & Variables & The k-s test amount & Sig. level \\
\hline 1 & Fluency & 1.132 & 0.074 \\
\hline 2 & Development & 0.944 & 0.081 \\
\hline 3 & Flexibility & 1.879 & 0.063 \\
\hline 4 & Initiative & 0.916 & 0.082 \\
\hline
\end{tabular}

As it can be seen in table 1, the distribution of variables is normal.

Table 2 shows the mean and standard deviation of the scores of the experimental and control groups. The findings of this study indicate that the scores of the experimental group in the post-test are higher than ones in the control group.

Table 2 .

The results of descriptive statistics

\begin{tabular}{|c|c|c|c|c|c|}
\hline \multirow{2}{*}{ Variable } & Stage & Statistical index & Mean & $\begin{array}{c}\text { Standard } \\
\text { deviation }\end{array}$ & No. \\
\cline { 3 - 5 } & Preativity & Group & & 0.4512 & 15 \\
\cline { 3 - 6 } & Post-test & Control & 32.482 & 0.5258 & 15 \\
\cline { 2 - 5 } & Experimental & 31.586 & 0.2361 & 15 \\
\cline { 2 - 5 } & $\begin{array}{c}\text { Difference be- } \\
\text { tween pre - and } \\
\text { post-test }\end{array}$ & Experimental & 48.055 & 1.9712 & 15 \\
\hline
\end{tabular}

The first hypothesis: Painting has a positive effect on the creativity of pre-school children. 
Table 3.

Analysis of covariance with determining the homogenization of the slope of regression line for the effect of training on creativity

\begin{tabular}{|c|c|c|c|c|c|c|c|}
\hline Component & source & $\begin{array}{c}\text { Sum of } \\
\text { squares }\end{array}$ & $\begin{array}{c}\text { Degrees of } \\
\text { freedom }\end{array}$ & $\begin{array}{c}\text { Mean } \\
\text { Square }\end{array}$ & F & $\begin{array}{c}\text { Sig. } \\
\text { level }\end{array}$ & $\begin{array}{c}\text { Eta } \\
\text { Square }\end{array}$ \\
\cline { 2 - 8 } & Group & 11.415 & 1 & 11.415 & 15.812 & 0.00 & 0.242 \\
\cline { 2 - 8 } & $\begin{array}{c}\text { Interaction of } \\
\text { group and pre-test }\end{array}$ & 0.851 & 2 & 0.425 & 1.875 & 0.41 & 0.086 \\
\cline { 2 - 9 } & Error & 1.616 & 27 & 0.059 & & & \\
\hline
\end{tabular}

According to the Table 3, the interaction between experimental conditions and covariate is not significant and the slope of the regression line is the same $(\mathrm{p}=0.41)$. The results of covariance analysis showed that there is a significant difference between the control and experimen- tal groups (educational interventions in changing creativity) (Partial Eta Squared is equal to 0.242, p $=0.000, \mathrm{~F}$ $=15.812$ ).

Second hypothesis: Fluency mean is different for the trained and non-trained children.

Analysis of covariance with determining the homogenization of the slope of regression line for the effect of training on fluency

\begin{tabular}{|c|c|c|c|c|c|c|c|}
\hline Component & source & $\begin{array}{c}\text { Sum of } \\
\text { squares }\end{array}$ & $\begin{array}{c}\text { Degrees of } \\
\text { freedom }\end{array}$ & $\begin{array}{c}\text { Mean } \\
\text { Square }\end{array}$ & F & $\begin{array}{c}\text { Sig. } \\
\text { level }\end{array}$ & $\begin{array}{c}\text { Eta } \\
\text { Square }\end{array}$ \\
\cline { 2 - 8 } & Group & 23.036 & 1 & 23.3036 & 17.857 & 0.00 & 0.242 \\
\cline { 2 - 8 } & $\begin{array}{c}\text { Interaction of } \\
\text { group and pre-test }\end{array}$ & 1.985 & 2 & 0.992 & 1.762 & 0.21 & 0.093 \\
\cline { 2 - 8 } & Error & 9.520 & 27 & 0.352 & & & \\
\hline
\end{tabular}

According to the Table 4, the interaction between experimental conditions and covariate is not significant and the slope of the regression line is the same $(p=0.21)$. Covariance analysis showed that there is a significant difference between control and experimental groups (edu-

Table 4.

cational interventions in the fluency variable) (Partial Eta Squared is equal to $0.242, \mathrm{p}=0.000, \mathrm{~F}=17.857$ ).

Third hypothesis: Development mean is different for the trained and non-trained children.

Analysis of covariance with determining the homogenization of the

Table 5 . slope of regression line for the effect of training on development

\begin{tabular}{|c|c|c|c|c|c|c|c|}
\hline Component & source & $\begin{array}{c}\text { Sum of } \\
\text { squares }\end{array}$ & $\begin{array}{c}\text { Degrees of } \\
\text { freedom }\end{array}$ & $\begin{array}{c}\text { Mean } \\
\text { Square }\end{array}$ & F & $\begin{array}{c}\text { Sig. } \\
\text { level }\end{array}$ & $\begin{array}{c}\text { Eta } \\
\text { Square }\end{array}$ \\
\cline { 2 - 8 } & Group & 28.009 & 1 & 28.009 & 21.398 & 0.00 & 0.282 \\
\cline { 2 - 9 } & $\begin{array}{c}\text { Interaction of } \\
\text { group and pre-test }\end{array}$ & 4.102 & 2 & 4.985 & 2.051 & 0.23 & 0.012 \\
\cline { 2 - 9 } & Error & 8.520 & 27 & 0.315 & & & \\
\hline
\end{tabular}

As it can be seen in the Table 5, the interaction between experimental conditions and covariate is not significant and the slope of the regression line is the same $(\mathrm{p}=$ 0.23 ). Covariance analysis showed that there is a significant difference between control and experimental groups (educational interventions in the development variable) (Partial Eta Squared is equal to 0.282, p $=0.000, \mathrm{~F}$ $=21.398$ ).

Fourth hypothesis: Initiative mean is different for the trained and non-trained children.

Analysis of covariance with determining the homogenization of the slope of regression line for the effect of training on initiative

\begin{tabular}{|c|c|c|c|c|c|c|c|}
\hline Component & source & $\begin{array}{c}\text { Sum of } \\
\text { squares }\end{array}$ & $\begin{array}{c}\text { Degrees of } \\
\text { freedom }\end{array}$ & $\begin{array}{c}\text { Mean } \\
\text { Square }\end{array}$ & F & $\begin{array}{c}\text { Sig. } \\
\text { level }\end{array}$ & $\begin{array}{c}\text { Eta } \\
\text { Square }\end{array}$ \\
\cline { 2 - 8 } & Group & 19.092 & 1 & 19.092 & 13.947 & 0.04 & 0.218 \\
\cline { 2 - 8 } & $\begin{array}{c}\text { Interaction of } \\
\text { group and pre-test }\end{array}$ & 3.085 & 2 & 1.542 & 2.709 & 0.8 & 0.031 \\
\cline { 2 - 8 } & Error & 6.590 & 27 & 0.244 & & & \\
\hline
\end{tabular}


According to the Table 6 , the interaction between experimental conditions and covariate is not significant and the slope of the regression line is the same $(\mathrm{p}=0.8)$. Covariance analysis showed that there is a significant difference between control and experimental groups (edu- cational interventions in the initiative variable) (Partial Eta Squared is equal to 0.218, $\mathrm{p}=0.04, \mathrm{~F}=13.947$ ).

Fifth hypothesis: Flexibility mean is different for the trained and non-trained children.

Analysis of covariance with determining the homogenization of the slope of regression line for the effect of training on flexibility

\begin{tabular}{|c|c|c|c|c|c|c|c|}
\hline Component & source & $\begin{array}{c}\text { Sum of } \\
\text { squares }\end{array}$ & $\begin{array}{c}\text { Degrees of } \\
\text { freedom }\end{array}$ & $\begin{array}{c}\text { Mean } \\
\text { Square }\end{array}$ & F & $\begin{array}{c}\text { Sig. } \\
\text { level }\end{array}$ & $\begin{array}{c}\text { Eta } \\
\text { Square }\end{array}$ \\
\cline { 2 - 8 } & Group & 19.039 & 1 & 11.096 & 14.809 & 0.00 & 0.202 \\
\cline { 2 - 8 } & $\begin{array}{c}\text { Interaction of } \\
\text { group and pre-test }\end{array}$ & 0.785 & 2 & 0.459 & 4.736 & 0.2 & 0.061 \\
\cline { 2 - 8 } & Error & 6.522 & 27 & 0.620 & & & \\
\hline
\end{tabular}

According to the Table 7, the interaction between experimental conditions and covariate is not significant and the slope of the regression line is the same $(p=0.2)$. Covariance analysis showed that there is a significant difference between control and experimental groups (educational interventions in the flexibility variable) (Partial Eta Squared is equal to 0.218, $\mathrm{p}=0.04, \mathrm{~F}=13.947$ ).

\section{Discussion and conclusion}

The findings showed that painting has a positive impact on the development of fluency, initiative, and flexibility of pre-school children of Shabestar kindergartens. The findings related to the abovementioned hypothesis are in line with the findings of Hejazi and Seif (2012), Hakimi (2012), Pakarian (2011), Karami and Heibati Allahi (2011), Eshaqnia (2010), Farshad (2009), Tashakori and collegues (2008), Haj Babaee (2007), Asadi (2006), Boulan-Diaz (2005), Danils (2000), Deivid (2000), Janson and Makan (2000), and Chambers (2000).

In explaining the abovementioned hypothesis, it can be said that childhood has a critical role in determining human life. Attention to this period can be explained by the fact that psychologists and education experts often consider childhood as the most prominent stage in the development of the human personality; they believe conflicts and mental disorders at this age are the main factors creating problems in the future life. One of the basic activities where pre-school children should be engaged is art, and especially painting. Children's drawings are a message that conveys what they cannot express in words. Children display the experiences of their lives by drawing, examine themselves, and establish their own "self".

The purpose of education is to create the desired changes in behavior. Creativity is a multidimensional process that involves the interaction between organisms and the environment, resulting in the emergence of new and unique phenomena. The desire to be creative is evident throughout history and in all human societies. Creation of myths in religious and cultural groups represents this desire. In the nineteenth century, Frobel believed that there was a relationship between creativity, imagination and inner lives of children. In 1950, Guildford in the Psychology Congress of America stated that creativity should not be considered as an exceptional gift that only
Table 7.

exists in some people, but it should be noted that creativity exists in all individuals more or less and at different ages (Duffy, translation by Yasaii, 2001).

Initiative is concerned with uniqueness or unusual ideas that are accompanied with the unusual, strange and subtle answers. Human beings are so creative and innovative that the ability to create has no limits for them, and human civilization is the result of their own creative force. But people have made little use of their creative potential so far. The twentieth century has discovered a new era in the field of creativity. During the twentieth century the mankind has designed and developed more inventions and innovations than ever before. This is just the initial stage of human creativity, and it is expected that the future of human creativity can reach the stage of growth and prosperity. What is certain is that every human being has the potential for creativity.

In the world of current developments, in which we witness intense competition of different communities to get the latest technologies and power sources, changes and progress in various economic and industrial aspects should be accomplished, otherwise we will lag behind contemporary societies and, consequently, will not be effective on the world stage.

Creativity is the combination of initiative, flexibility and sensitivity to criticism, which enables a learner to think about different and productive results, which leads to personal fulfillment.

The most common perception of creativity is that a person presents new and different thinking. Basically, creativity will not always convert to a visible result; for example, a child creates something new and different in the world of imagination but his/her intellectual creation is not visible for others and, therefore, it cannot be evaluated. According to the results of the study, painting contributes to children's flexibility, fluency, and finally creativity. Thus, according to the research results, one can state that painting has a significant positive effect of the development of children's creativity. So in order to develop creativity in children, curricula for kindergartens and other preschool educational institutions should contain Art classes. 


\section{REFERENCES}

1. Asadi, M. (2006). The relationship between preschool training and social development of first and second grade students in elementary public schools in Tehran. MA thesis, Tarbiat Modarres University in Tehran.

2. Asadi, Z. (2011). The necessity of creativity growth and entrepreneurship of children to provide human resources of future organizations. Tehran, Publisher of New Thought.

3. Amir Jahani, S. H. (2011). An Inquiry into the concept of art and its composition elements. Retrieved from: firooze.com.

4. Boulan-Diaz, A. (2001). Behavioral research: A systematic approach. London: sage publications New York: John Wiley \& Sons.

5. Chambers, H. (2000). Fundemental of an $a b$ normal psychology. New York: John Wiley \& Sons.

6. Danils, M. (2000). Beliefs and behavior. Cognitive therapy and research, 19, 66-94.

7. Deivid. M. (2000). Contemporary behavior therapy. Handbook of psychological change: Psychotherapy process $\&$ Practice for the 20 st century. New York: wiely.

8. Elhami, H. (2013). The effect of pre-school education on mental and academic development as well as emotional and social adjustment of school children of Torbath E Heydarieh city. MA thesis. AllamehTabatabaei University in Tehran.

9. Eshaqnia, R. (2010). Modern art and children's drawings. Tehran: Iranian art News.

10. Faraji, M. (2012). Art education in pre-school centers. Tehran: Pre-school site of education organization in Tehran.

11. Farshad, M. (2009). The effect of pre-school education on academic achievement and social development of primary students in Tehran.the Department of Education in Tehran.

12. Gharika, B. (2001). The development origins of cognitive vulnerability to depression: Negative interpersonal context leads to personal vulnerability. Cognitive therapy and research, 22, (Vol. 2), 792-712.

13. Haj,Babaee. (2007). The relationship between motor abilities and academic achievement in elementary fifth grade students of Tehran's district four.M.A. thesis. University of Allameh Tabatabaei.
14. Hakimi, A. (2012). Enrichment effect on mental and psychomotor development of nursery children. Reflection, 2.

15. Hejazi, E. \&Seif, S. (2012). The effect of preschool education on academic achievement among elementary students. Proceedings of the Congress of preschool children. November 13-14. University of Welfare and Rehabilitation Sciences.

16. Hosseinzadeh, S. (2010). Investigating the relationship between pre-school training with social adjustment of first-grade elementary students of Tehran province in the academic year 2009-2010. Tehran: Ministry of Education.

17. Janson. K. \&Makan.N.(2000).Social and personality development. London: Pergamon press.

18. Jorjani, M. (2011). Interaction between parents and children. Tehran: Growth.

19. Karami, M. \&HeibatAllahi, A. (2011). The effect of pre-school education on the relationship between social adjustment of students from the first grade of elementary schools of districts 1 and 2 of Sanandaj city. A summary reports on education research.

20. Kazemi, M A. (2012). Ways to foster creativity. Journal of Knowledge, 92, Special Edition of Educational Sciences.

21. MirzaAqaei, H. (2002). Children, the greatest teachers of creativity. Entrepreneurship Special Issue of Trust Newspaper.

22. Pakarian, S. (2011). Analysis of the pre-school program and its impact on academic achievement and social development of elementary school students in Isfahan. M.A. thesis. TarbiatMoallem University of Tehran.

23. Perkins. D. (2002). Personality and problems of afjustment. $\left(9^{\text {th }} \mathrm{ed}\right)$. London: Routledge Current psychotherapies. Itasca: F. E. Peacock publishers, Inc.

24. Taleei, A. (2013). The effect of pre-school education on academic achievement and intelligence of children in primary school. Journal of Educational Sciences. Faculty of Education and Psychology, 3, 4 (Vol. 8).Tehran University.

25. Tashakori, R. \& Sotudeh, M. (2008). The effect of pre-school education on the academic performance of students from the first grade to third grade of Bojnoord elementary schools. Teacher Development, 7, 25-30.
Шахін Самадпур Шахрак, мazicmp,

Парвіз Карімі Сані, кандидат наук, кафедра психології, Рогайе Хамізаде, кандидат наук, кафедра психологіі, Ісламський університет Азад, Шабестар, Іран,

\section{ДОСЛІДЖЕННЯ ВПЛИВУ МАЛЮВАННЯ НА РІВЕНЬ КРЕАТИВНОСТІ ДОШКІЛЬНИКІВ}

Статтю присвячено вивченню впливу малювання на рівень креативності дошкільників. Дослідження проводилось на базі дитячих садочків міста Шабестар (всього 620 дітей). Вибірку склали 30 випадково відібраних дошкільників, які відвідували дитячий садочок у 2014-2015 р., яких було поділено на контрольну та експериментальну групи по 15 осіб у кожній. 3 експериментальною групою проводилися спеціальні заняття 3 мистецтва 
(малювання), а контрольна група навчалася за звичайним навчальним планом без будь-яких змін. Методика, за якою навчалися діти експериментальної групи, була розроблена Вільямом Гордоном та колегами, яку було адаптовано для дошкільників. Вона включає такі 9 секцій: малювання на вільну тему; малювання довільних ліній; малювання на задану тему: люди, тварини, фрукти, квіти; ілюстрація за оповіданням; завершення незакінчених малюнків; гравюра а) на натуральних матеріалах, б) на синтетичних матеріалах; поєднання малювання та майстрування; поєднання малювання з тренуванням сприйняття на слух; поєднання малювання 3 вигадуванням історій та їх презентацією. Кожна секція розрахована на 30-60 хвилин. Окрім цього, також було використано Тест на креативність (автор - Абеді), який складається з 30 запитань та може використовуватися для будьякого віку. За результатами експерименту було виявлено, що малювання дійсно позитивно впливає на розвиток креативності дітей. Окрім цього, також було досліджено такі якості дітей, як гнучкість, ініціативність та вміння малювати як складові креативності. За усіма показниками після проведення експерименту діти експериментальної групи випереджали дітей контрольної. Тож рекомендовано до навчальної програми дошкільників у дитячих садочках додавати уроки мистецтва, зокрема малювання.

Ключові слова: малювання, креативність, вміння малювати, розвиток, ініціатива, гнучкість, дошкільники.

Подано до редакиіï 21.12.2016

UDC: $373.2+159.954$

\author{
S. Zahra Shahnemati, \\ Master-Degree student, Department of Educational Science, \\ Islamic Azad University, Isfahan (Khorasgan) Branch, \\ Isfahan, Iran, \\ Zohreh Saadatmand, \\ associate professor, Department of Curriculum Planning, \\ Isfahan (Khorasgan) Branch, Islamic Azad University, Isfahan, Iran, \\ Narges Keshtiaray, \\ associate professor, Department of Educational Sciences, \\ Islamic Azad University, Isfahan (Khorasgan) Branch, Isfahan, Iran
}

\title{
PHENOMENOLOGY OF TEACHERS' EXPERIENCE IN TEACHING ART TO PRIMARY SCHOOL STUDENTS
}

The study is aimed at investigating teachers' experience of teaching Art at primary school. The survey involved Art teachers in Marvdasht and Shiraz cities in Fars Province. The participants were selected using snowball sampling method. Deep semi-structured interviews were used to collect information. The data analysis has been performed by thematic coding. The results have shown that the teachers use such teaching methods as working in small groups, role playing, group discussion, etc. in their practice. Considering the fact that the major part of knowledge is learned by students in the classroom the teaching quality is one of the most important factors in student' achievements. Thus, teachers should strive to improve the quality of teaching.

Keywords: methods of teaching Art, teaching skills, Art lessons, teaching experience.

Introduction. Many psychologists and education specialists deal with the searching for ways to develop and improve the educational process in general and teaching methods in particular. Despite numerous researches in this area, the results are varying due to various affecting factors in the field of teaching methods so that educators do not come up to a conclusion about one specific teaching method which would improve the educational process. Preparing students for living in today's difficult and complex conditions requires the improvement of the quality of teaching and learning expertise. Paying thorough attention to the teaching experience of teachers around the world is one of the strategies to meet the needs of the education in every country.

"Наука і освіта", № 12, 2016
Art is one of the most mysterious aspects of human culture and civilization that always pervades human life. According to Lancaster (1990), art is a part of the human creativity through which people communicate with each other. Art includes that part of human creativity through which human beings transfer their feelings, thoughts and emotions expressed in visual interpretation of the environmental experiences to others using artistic tools and handicrafts. However, the success in this field depends on artistic features of a person (Amini, 2006).

From the dawn of human history, art, in its various forms, has had a significant role in human life so that it can be said that human beings have stated their inner desires, attitudes, emotions and creativity even through 